\title{
TRANSFORMATION PROCESSES IN THE DEVELOPMENT OF THE FINANCIAL AND ECONOMIC AS WELL AS COOPERATIVE EDUCATION IN THE WESTERN TERRITORIES OF UKRAINE (THE SECOND HALF OF XIX - THE BEGINNING OF THE XX CENTURY): STATE, PECULIARITIES, GALICIAN LEADERS, EDUCATIONAL ASSOCIATIONS, THEORETICAL METHODOLOGY
}

\author{
Mykhailo HOLUBKA ${ }^{1}$ \\ Lviv Cooperative College of Economics and Law, Ukraine
}

\begin{abstract}
In the article, the transformation processes of the development of financial and economic as well as cooperative education in the Western territories of Ukraine in the second half of the XIX - the beginning of the XX century, its state, peculiarities, scientific results of Galician figures, educational associations, historical and economic aspects were covered. The methodology and the general essence of the financial and economic as well as cooperative education, the high importance of its quality were found out. The significance of financial and economic as well as cooperative education for realizing the opportunities for the self-understanding of a human as an economically active member of the nation was identified. The purpose of this study is to find out the personal and the peculiarities of the financial and economic as well as cooperative education in the Western territories of Ukraine in the second half of the XIX - the beginning of the XX century with the transformation on the processes that take place under the modern conditions of the development of the national education system. Methodology. The features and the transformation processes which defined environment conditions for financial and economic as well as cooperative education in the second half of the XIX - the beginning of the XX century on the territory of Western Ukraine were identified. Special attention is paid at the identification of financial and economic as well as cooperative education with business culture that includes the need to consider the public interest. A very important role of activation of the cooperative movement in the Ukraine Western territories that were not independent was admitted. The institutional framework of the development of the financial and economic as well as cooperative education of the population that has proved a key role in these processes and various institutions of self-education partnerships was analyzed. The broad functionality of such associations and the transformation of the main goal of its activities from educational proper to educational, financial and economic were revealed. The basic achievements of associations and associates in terms of the support for the establishment of various organizations for the business purposes, cooperatives, educational institutions, professional courses, publishing, organization of specialized events, financial institutions, etc. were described. The performance of other institutions was researched; their main activities for the development of financial and economic as well as cooperative education of the population in the Western territories of Ukraine in the second half of the XIX-the beginning of the XX century were specified. Taking into consideration the significant role of the cooperative movement for the formation of financial and economic as well as cooperative education of the population at that time, some economists-philosophers and their lay-outs in the advantages of this form of economic activity were mentioned. The characteristics of financial and economic as well as cooperative education in the Western territories of Ukraine in the second half of the XIX-the beginning of the $X X$ centuries with a focus on national values, self-organization, dissemination of professional schooling, which were a prerequisite for the further development of the system of the higher financial and economic as well as cooperative economic education were provided. Practical implications. Financial and economic as well as cooperative education is becoming an important subject of research for the Ukrainian scholars because of the significant gaps in its quality assurance. In spite of the sufficient amounts of trained professional economists, a workforce lack remains in the
\end{abstract}

\footnotetext{
Corresponding author:

${ }^{1}$ Department of Finance and Credit, Lviv Cooperative College of Economics and Law E-mail: Golubka_mikki@ukr.net
} 
areas of financial management, accounting and auditing, insurance, Internet commerce, etc. It is quite negative, as the high quality of financial and economic as well as cooperative education has a significant potential positive impact on the economy and business in general. As L. Zahlynska and A. Lukomska admit, it is revealed in improving the investment efficiency, not only in education but also in other sectors of economy; attracting people to the development of entrepreneurship and acquisition of new enterprise features to increase the number of small and medium enterprises; increasing the number of the self-employed in the national economy sectors; enhancing the competitiveness of Ukrainian population on international labor markets, its confidence in the effective employment, actualization of possibilities and desires of each person will contribute, in their turn, to establishing a progressive civil society (Zahlynska, 2014). The main objective of the financial and economic as well as cooperative education is realizing the opportunities for the individuals to self-actualize as a financially and economically active member of society who is able to be consciously engaged in financial and economic as well as cooperative life of the country (Tovkanets, 2014). Therefore, in the context of structural and functional framework, financial and economic as well as cooperative education is intended not only at generating relevant knowledge, but also at applying them for social development. Material of the considered article can be used for the preparation of teaching aids, seminars and training courses on financial and economic as well as cooperative issues. Value/originality lies in the fact that the subject is not widespread among Ukrainian researchers in economics and more often gets the focus of the scholars-pedagogues. We made an attempt to explore this area in the light of financial and economic direction of cooperative education and its need for the Ukrainian society on the territory of Western Ukraine in the end of the $\mathrm{XIX}$ - the beginning of the XX century as well as the importance of getting education, independence and well-being of the community from an economic point of view.

Key words: financial and economic as well as cooperative education, territories of Western Ukraine, economic culture, cooperative movement, vocational schooling, educational associations, Galician figures.

JEL Classification: B1, G34, O16

\section{Introduction}

Prerequisites, state and development of financial and economic as well as cooperative education at the Western territories of Ukraine in the late XIX-the beginning of the $\mathrm{XX}$ century are characterized by the specific historical and economic aspects. Thus, in the modern sense, during this period, the Ukrainian lands were divided between the Austrian Empire (the lands of Eastern Galicia and Northern Bukovyna), Kingdom of Hungary (Transcarpathia) and the Russian Empire (the majority of the Ukrainian lands). Correspondingly, in the area of the financial and economic as well as cooperative education in Western Ukraine at that time there was a significant influence of the Polonization policy (Eastern Galicia), Romanization (Northern Bukovyna), Hungarization (Transcarpathia) and Russification. The abovementioned differences in education were peculiar before the events of the World War I that marked the collapse of Austro-Hungarian, German, Ottoman and Russian Empires. As it was written by L. and I. Potapiuk, in the territories of Western Ukraine in the end of the XIX - the beginning of the XX century, economic education was characterized by the foundation and the tradition of the community self-help in the housekeeping of the Ukrainian people, the emergence of the first consumer societies, credit unions, co-operative movement, their fight against usury and illerateness (Tovkanets, 2014). Financial and economic as well as cooperative education was often considered as economic culture, which emphasized its social basis, taking into account the interests of others. It is noteworthy to understand that at that time only a very small percentage of Galicians were literate. The population, in particularly townsfolk, was subjected to the strict tax collection system that involved a so-called executioner. It was difficult for an inhabitant of that time to understand the need to pay fees and charges without getting the adequate social benefits and development opportunities as we have today. Moreover, the end of the nineteenth century was marked by the adaptation of the population to the abolition of serfdom and the actual construction of a new system of relations that are increasingly based on the principles of coherence and minimization of coercion. The period under consideration was an important progressive step for the industry, development engineering, oil and coal mining. Therefore, society got a chance to respond to the global and the local progressive challenges, developing the intellectual environment of the local (not always purely Ukrainian) origin and develop financial and economic as well as cooperative education.

\section{Influence of the financial and economic as well as cooperative education to developing the quality and behavior of a nation}

The review of financial and economic system as well as cooperative education in the territories of the Western Ukraine in the second half of the XIX - the beginning of the XX century is an important subject of research. This period reveals the features of the situation in the Ukrainian territory, which was controlled by Austria-Hungary and implemented the policy of the more loyal socio-cultural 
development than in the Russian Empire. This made it possible to develop a holistic space that was societal enough to form West Ukrainian People's Republic, though it did not exist for a long period of time.

For any society, the level of financial and economic as well as cooperative education is a sign of its intelligence and opportunities for the further development. As a rule, the specialists of the financial and economic as well as cooperative area include leading power figures, the active agents of the influence of the financial and economic situation in the country. Therefore, a holistic development of the national educational system should focus on the historical features of formation of its economic component, improving positive aspects and leveling negative ones. The relevance of the topic chosen for the study confirms the need for the scientific substantiation of priorities in improving the quality of economic education in Ukraine with the understanding of the retrospective foundations of its formation in the context of different time periods.

\section{Development of financial and economic as well as cooperative education in Western Ukraine in the second half of the XIX - the beginning of the XX century in terms of the specific socio-economic transformations}

Besides, in the second half of the XIX - the beginning of the XX century, the strategically important changes, the development of the financial and economic as well as cooperative education in the Western territories of Ukraine were ensured in terms of the specific socioeconomic transformations. First, it is a period of cooperative movement, which is an important indicator of economic culture of the population, especially farmers. A prerequisite for the development of cooperatives was the adoption of the Austro-Hungarian law on the income and economic union in 1873. Its purpose was to prevent the bankruptcy of small producers. In fact, this law regulated the obligation of cooperatives development throughout the empire. In this way, the government sought to boost tax revenues to the regional budget.

The institutional foundations of economic activity was strengthened by the public education associations «Prosvita» ("Enlightement") (founded in 1868), «Ridna Shkola» ("Native School") (founded in 1881). Although these bodies were of even more cultural and educational guidance, and were intended at unification of the Ukrainian lands «from the Carpathians to the Kuban», their activity was important from the perspective of developing certain ideological standards that were necessary to understand the need for financial and economic knowledge, the priorities of the economic and cooperative development of the West Ukrainian lands in the unity and the opposition of the colonizers' areas. These governing bodies included many lawyers, artists, historians, and writers; however, the leaders were teachers. It was an important center of intellectual communication with the formation of their vision on development. «Prosvita» was especially significant and in 20 years of activity it has changed its main cultural and educational purpose into educational and economic one and began to pursue financial and economic cooperative activities promoting cooperation intensively (Potapiuk, 2015). From 1906 to 1912, its representatives have organized 15 cooperative courses, higher education courses, contributed to the development of schools, including the economic one in Ugertsy Venyavski (now the village Zelenyi Hai in Lviv region), established a trade school in Lviv in 1911 (T. Shevchenko). Other initiatives of «Prosvita» were the following (this list is not complete) (Levytsky, Russ Folk Society in Lviv, Zuliak I. (2010):

- the foundation of the "Association of Mutual Cooperation «Dniester» in Lviv,» which numbered 213,943 policies in 3733 communities totaling $218,043,491$ crowns of $2,159,903$ crowns of the premium fund and 1,000,000 crowns of the reserve fund, holding thousands in the land agencies at the end of 1907;

- the foundation of the Mutual Credit Society «Faith» in Przemysl, 1894;

- the foundation of the «Land Credit Union» in Ukraine in 1898, which included 230 members in 1899, and its authorized capital amounted to $11,236,754$ crowns, the amount of loans granted to Ukrainian institutions was 21,700 crowns;

- the foundation of a «Land Revision Union» and «Land Household and Milk Production Union» in 1904 and 1907 with the center in Lviv;

- the foundation of the «People's Trade» or «Commercial Union» in 1908, which had branches in 14 districts and provided an annual one-month training course for 12 trainees;

- the foundation of such Associations as "Farmer" and "Rus Shchadnytsya" in Przemysl in 1904 and 1905 respectively.

In general, as I. Zuliak admits, at the end of 1908, there were 227 business partnerships supported by «Prosvita»; they comprised 168 credit, 21 commercial, 10 industrial, 10 commercial agriculture and 9 milk production associations and 9 associations of other types (Zulyak, 2010). The Company used the practice of teacher-trainers who traveled to different settlements and promoted leading economic ideas of the time. In the process of their educational and economic as well as financial campaign, the organization became much more active and achieved considerable success.

The role in the development of financial and economic as well as cooperative education was played by an economic partnership «Audit Union of Ukrainian Cooperatives» (AUUC), in particular in its body «People's Trade» (the first Ukrainian Cooperative), «Farmer», «Butter Production Union», «Central Union», «Central Bank», etc. It should be noted that «Farmers $\gg$ that was founded in 1899 , organized the training of selected Galicians abroad. Generally, this body was significantly developed after 1909, with a sufficient network of branches and over 25 thousand 
of Members. This profiling body played a significant role in shaping the economic education of persons who were engaged in agriculture, thereby developing vocational education. In accordance with the researches of $\mathrm{L}$. and I. Potapiuk, the scholars, the most important areas of society were the following: the foundation of various industrial and economic unions, promotion of agricultural knowledge among the population, organizing reading rooms, libraries, agricultural and industrial schools; congresses, courses and exhibitions, setting up model farms, experimental stations, mediation in buying land, artificial fertilizers, tools, marketing of agricultural products, publishing weekly $\ll$ Economic Journal», brochures in the series «Library of a Farmer» (Potapiuk, 2015).

An important functional role was played by the first Ukrainian cooperative «People's Trade», established in 1883. During the first year of its activity, the amount of its members increased from 64 to 700 people. Membership in such institution was a great opportunity not only for practical application of economic knowledge, but also for their level improvement. As I. Franko found out in his economic writings, being well aware of the peculiarities of trade and business activities of the time, the cooperative took the top spot in the Galician merchant world and was a quite structurally capable organization, had trade relations with a network of village shops; and this useful body deserves the best possible development (Franko, 1985).

It is necessary to understand that the operation of these organizational bodies had both direct and indirect impact on the financial and economic as well as cooperative education in the region. On the one hand, they served as the centers of formation of financial and economic as well as cooperative literacy of population, organization of a system of people's links with the corresponding potential lay-outs. On the other hand, such associations developed educational infrastructure, gave access to economic knowledge for even illiterate population, with the possibility of its use in everyday life and the future in their own economic activity. They also had exceptional institutional values, demonstrated the ability of people to self-develop and adjust to progressive challenges.

The high institutional organization of financial and economic as well as cooperative education in the territories of the Western Ukraine resulted in the First Ukrainian Educational and Economic Congress, the main organizer of which was the Association «Prosvita» in 1909. This congress was held in Lviv and counted more than 750 participants from all over Ukraine. I. Zuliak believes that the main objective of this meeting was the critical reflection and the evaluation of activities, finding the ways and the methods to improve financial and economic state of the Ukrainian peasantry; participation in the congress of all population groups showed interest to change the existing social and economic order in rural areas, thus, it made a contribution to a significant economic recovery in Eastern Galicia and, correspondingly, the increase of the economic welfare of the Ukrainians (Zulyak, 2010). Such measure indicates a sufficient level of economic education of both the entities involved in the related business processes and the willingness of other members of society to develop relevant skills. There is no doubt that this extraordinary event did not remain unnoticed both in the society and at the highest level, and positioned the western lands as active economic agents in the European scale.

\section{Financial and economic as well as cooperative education in Western Ukraine in the second half of the XIX - the beginning of the $X X$ century was ensured and advocated by numerous academic printed materials and Galician figures}

The development of financial, economic and cooperative education of that time was provided by the numerous academic printed materials. A separate direction that they formed was the idea of cooperative movement. It was advocated in the writings of many Galician leaders of the studied period:

- Augustine Voloshyn, who proved the benefits of cooperatives and achieved the introduction of cooperative laws in Transcarpathia; they protected Transcarpathian contributions of cooperative unions in Budapest banks that had been devalued after the joining edge to the Czechoslovak Republic in the publication «Science» and other writings (Myshanych, 2002);

- Denys Korenets, who actively promoted and implemented the models of the staged trade and cooperative education, studied relevant international experience, analyzed the economic, socio-cultural, demographic factors and areas of development (Hipters); - Yulian Dzerovych, who was a member of the priestly cooperative «Self-Help», the publishing cooperative «Target», longstanding member of the Board of Trade Inspector-Industrial Cooperative «Delivery» engaged in the production and supply of religious things; Yu. Dzerovych was well aware of the importance of cooperation for fostering a sense of responsibility and the powers of the national community as once working in co-operation, the average person stops to think only about themselves and thinks about the whole, he/she becomes a citizen (Pastushenko, 2011);

- Karl Kobersky, who was a cooperative editor of the «Cooperative Republic» journal and other publications of AUUC;

- Yulian Pavlykovskyy who underscored the valuable role of cooperatives in the Ukrainian society, called for the creation of the new cooperative centers in the county and in the region to strengthen the Ukrainian element in cities and disengaging from the Polish co-operation (Potikha, 2011);

- Stepan Smal-Stotskyi, who revealed the historical aspects of economic development of Bukovyna (in his work «Bukovyna Rus» in 1897), was an editor of the «Russian Council» newspaper as well as the co-editor of 
the «Bukovyna» newspaper and promoted the idea of the cooperative movement;

- Yevhen Khraplyvyi, who was the editor of the «Economic and Co-operative Magazine» journal and other publications of the later period as well as the author of numerous works on the dissemination of agricultural cooperatives;

- Yevhen Olesnytskyy, a member of the editorial board of the "Business" magazine, where he often published his articles that covered the professional analysis of economic relations in the region. (Pynda, 2015).

In general, the analysis of financial, economic, political, psychological, pedagogical literature of the time shows that many homeland philosophers, educators, financiers, economists saw the spiritual and moral aspects of the market economy means not only improve efficiency, but also the moral development of people (Hipters, 2011).

\section{The Features of the Formation of Financial, Economic and Cooperative Education in the Western Territories of Ukraine in the Period under Consideration}

Among the characteristic features of the formation of financial and economic as well as cooperative education in the Western territories of the studied period, it is important to focus on the development of the professional (vocational) school system with the expansion of the so-called "bursas". Its impetus was the law on the organization of 1872 , which authorized their national separateness; as L. and I. Potapiuk admit, this regulation allowed the establishment of the private schools that directly concerned vocational school system, which promoted various Ukrainian economic and cultural as well as educational institutions, societies that made people understand the need for establishing professional schools as a means of salvation poverty (Potapiuk, 2015). A common trade school was designed to provide the basic knowledge in different trade areas. Positively, in this period, a system of extracurricular trade practices developed. Thus, a larger number of young people could decide with their inclinations towards trade and economic affairs.

The period of the end of the XIX century manifested more in the development of financial, economic and cooperative education at schools. Higher studio has not been so powerful yet. For example, in the end of the nineteenth century at Lviv University there were only three departments: law, theology and philosophy ones. Since 1891, the Medicine Department was founded. The Economics Department started its activity only in 1966. However, vocational schooling, institutionalized cooperative movement to support public structures undoubtedly led to an input for the establishment of the high financial and economic as well as cooperative education in Galicia and other territories of Western Ukraine.

\section{Results}

In the process of study, we have revealed the general nature of the financial and economic as well as cooperative education and the importance of improving its quality in Ukraine, identifying the environmental conditions of economic education in the territory of Western Ukraine in the end of the XIX - the beginning of the XX century and held characterization of the major public institutions on the formation of economic public education, allocation of the most representative features of the contemporary financial, economic and cooperative education as well as cooperative economic manifestations of culture, vocational schooling, extracurricular trade practices, specialized publishing activity and libraries.

\section{Conclusions}

Therefore, the transformation processes of financial and economic as well as cooperative education in the Western areas of Ukraine in the end of the XIX - the beginning of the XX century was predetermined by the colonial status of Eastern Galicia, Northern Bukovyna and Transcarpathia. Under the conditions of absence of any state support of educational attainment of the population in the end of the XIX - the beginning of the XX century, Ukrainian society demonstrated the vital feature of self-organization. The activities of the companies have shown the existence of the Ukrainian intellectuals who were capable of combining and distributing the national ideology. Significantly, at that time, the characteristic feature of the economic and financial co-operative education was its national principles, which are so lacking nowadays. Obviously, this experience should be adjusted to the modern conditions, strengthen the national-patriotic sentiments of modern financiers, economists and cooperators. The conducted research demonstrated that intellectuals, cultural and educational, cooperative leaders and others strongly contributed to the development, establishment and operation of financial, economic and cooperative education in the Western territories of Ukraine, provided great organizational, practical, educational activities to solve the problem of illiteracy, developed education and improved material welfare of the citizens, protected social, cultural, educational and spiritual needs of Ukrainians at the time. 


\section{References}

Holubka, M. (2016). Historical and Economic Aspects of Financial, Economic and Cooperative Education in the Territories of Western Ukraine (the Second Half of the XIX - the Beginning of the XX Century): Characteristics, Development, Trends. Recent trends of ensuring the efficiency of the economy: Proceedings of the International Scientific conference. East Institute of Economics and Management. Zaporizhzhya: NGO «SIEU». Part 1, pp. 38-41. Holubka, M. Educational Activities of Cooperative Centrals in the Western Territories of Ukraine in the second half of the XIX -the beginning of the XX century and Their Importance for the Promotion of Financial, Economic and Cooperative Education. Retrieved from: http: //www.spilnota.net.ua/ua/article/id-1499/

Holubka, M. (2016). The Development of the Economy and Financial-Economic as well as Cooperative Education in the Western Territories of Ukraine (the Second Half of XIX -the Beginning of the XX century). Finance, Audit and Management: Trend Analysis, Scientific and Economic Development: Materials of the International Scientific Conference. NGO «Lviv Economic Foundation». - Lviv: LEF, 2016.

Holubka, M. Scientific Area of Economic Thought in Western Academia (the second half of the XIX - the beginning of the XX century.) as a Part of Educational Western Intellectual World and Its Prestige in the Financial, Economic and Cooperative Education. Retrieved from: http: //www.economy-confer.com.ua/full-article/1992/

Holubka, M. (2016). Educational Activities of the Audit Union of of the Ukrainian Professional Cooperatives in Financial, Economic And Co-Operative Education Courses in Directing Financial, Economic and Cooperative Education at Western (second half of XIX - early XX century.). Problems and perspectives of innovation development. Materials HHHVIII International scientific conference, Chernivtsi, 2016, vol. 1, pp. 26-29.

Holubka, M. (2016). System of Factors of Economic Development and Financial-Economic and Cooperative Education in the Western Territories of Ukraine (the Second Half of the XIX - the Beginning of the XX Century.) Financial security and prospects of socio-economic systems: Proceedings of the All-Ukrainian scientific-practical conference. - K.: PO «Kyiv Economic Research Center». Part 1, 9-13 p.

Levytsky, K. The Start of Our Economic Institutions Development: 1890-1900. The First Ukrainian EducationalEconomic Congress Organized by the Association «Prosvita» in Lviv on the 1st and the 2nd of February in 1909,560 p.

Myshanych, O.V. (2002). Life and Work of Augustine Voloshyn. Uzhgorod: OJSC «Publisher» «Transcarpathia», 47 p. Pastushenko, N. (2011). Inexhaustible Source of Pedagogical Wisdom. Educational Thought. By the 140th anniversary of the birth of Julian Dzerovych, № 1, p. 5-23.

Potapyuk, L. M. (2015). Formation of Economic Education on the Example of the Western Communities (late XIX - early XX century). Economic Forum, № 2, p. 5-12.

Potikha, O. (2011). The Peculiarities of the Relations of the Ukrainian National Democratic Alliance with the Economic Societies of Western Ukraine (1930-1935). Mandrivets., № 5, p. 54-57.

Pynda, L. A. (2015). Yevhen Olesnytskyy - a Conductor of the Ukrainian Cooperative Movement in Galicia and the Tillage of the late XIX - the early XX century. History of Science and Biography, № 4. Retrieved from: http://nbuv.gov.ua/UJRN/INB_Title_2015_4_14

Russ Folk Society in Lviv. Illustrated calendar of the public association «Prosvita» in year 1900, Part 23, Bk. 1-2, p. 198-202.

Taras Shevchenko All-Ukrainian Association «Prosvita»: Wikipedia. The free encyclopedia [Electronic resource]. Retrieved from: https://uk.wikipedia.org/.../Всеукраїнське_товариство_«Просвіта»_іме...

Tovkanets, H.V. (2014). Teaching Analysis of the Tasks of the Higher Economic Education in Ukraine. Scientific Bulletin of the Uzhgorod National University, Series: Pedagogy. Social work. Uzhgorod: Hoverla, Vol. 31, p. $182-185$.

Zahlynska, L.V. (2014). Economic Education in the Context of Investment Processes in the Area. Update of the Content, the Forms and the Methods of Training and Education in Educational Institutions, vol. 9, p. 73-76.

Zulyak, I.(2010). The Role of «Prosvita» in the Dissemination of Economic Knowledge in Eastern Galicia (the end of the XIX - the Beginning of the XX century). Ukraine: Cultural Heritage, National Identity, Statehood. Vol. 19, p. 151-159.

\section{Михаил ГОЛУБКА}

ТРАНСФОРМАЦИОННЫЕ ПРОЦЕССЫ РАЗВИТИЯ ФИНАНСОВО-ЭКОНОМИЧЕСКОГО И КООПЕРАТИВНОГО ОБРАЗОВАНИЯ НА ЗАПАДНОУКРАИНСКИХ ЗЕМЛЯХ (ВТОРАЯ ПОЛОВИНА ХІХ - НАЧАЛО ХХ ВЕКА): СОСТОЯНИЕ, ОСОБЕННОСТИ, ГАЛИЦКИЕ ДЕЯТЕЛИ, ПРОСВЕТИТЕЛЬСКИЕ ОБЩЕСТВА, ТЕОРЕТИЧЕСКАЯ МЕТОДИКА

Аннотация. В статье исследованы трансформационные процессы развития финансово-экономического и кооперативного образования на западноукраинских землях во второй половине XIX - начале XX в., его состояние, особенности, наука галицких деятелей, просветительские общества и историкоэкономические аспекты. Установлено методологию и общую сущность финансово-экономического и 
кооперативного образования, высокую значимость ее качества. Указано на значение финансово-экономического и кооперативного образования для понимания возможностей самореализации человека как экономически активного члена нации. Целью данного исследования является определение личностей и особенностей развития финансово-экономического и кооперативного образования на западноукраинских землях во второй половине XIX - начале XX В. с трансформацией установлених процессов на современные условия развития отечественной образовательной системы. Методология. Определены характерные черты и трансформационные процессы во второй половине XIX - начале XX B. на территории западноукраинских земель, которые определяли в среде условия развития финансово-экономического и кооперативного образования населения. Обращено внимание на отождествление финансово-экономического и кооперативного образования с хозяйственной культурой, включая необходимость учета общественных интересов. Отмечено очень высокую роль активизации кооперативного движения на западноукраинских территориях, которые были подневольные. Проанализировано институциональную основу развития финансово-экономического и кооперативного образования населения, показано ведущую роль в данных процессах институтов самоорганизации и различных просветительских обществ. Раскрыто широкую функциональность данных обществ и трансформацию основной цели их деятельности по просветительской на образовательно-финансово-экономическую. Описаны основные достижения обществ, сподвижников в плане поддержки создания различных организаций как объединений и с целью коммерческой деятельности, кооперативов, учебных заведений, профессиональных курсов, издательской деятельности, организации профильных мероприятий, финансово-кредитных учреждений. Исследованы результаты деятельности других институтов, с конкретизацией их основных мер по развитию финансово-экономического и кооперативного образования населения западноукраинских земель во второй половине XIX - начале XX в. Учитывая значительную роль кооперативного движения для формирования тогдашней финансово-экономического и кооперативного образования населения, упомянуто отдельных экономистов-мыслителей и их наработки относительно преимуществ данной формы организации хозяйственной деятельности. Указано на характерные черты развития финансово-экономического и кооперативного образования на западноукраинских землях во второй половине XIX - начале XX в. с ориентацией на национальные ценности, самоорганизации, распространение профессиональных школ, что стало предпосылкой для дальнейшего развития системы высшего финансово економического и кооперативного образования. Практическое значение. Финансово-экономическое и кооперативное образование сегодня становится актуальным предметом исследований украинских ученых в силу значительных пробелов в обеспечении ее качества. При достаточных объемах подготовки специалистов-финансистов-экономистов остается працедефицит профессиональных кадров в области финансового менеджмента, учета и аудита, страхования, Интернет-торговли и других. Это очень негативно, ведь высокое качество финансово-экономической и кооперативного образования имеет значительный потенциал позитивного влияния на развитие экономики и предпринимательства в целом. Как пишут Л. Заглинська и А. Лукомский, он раскрывается в: повышении эффективности инвестиций не только в образовательной, но и в другие отрасли экономики; привлечении трудоспособного населения к развитию предпринимательства и приобретения новых черт предприимчивости в целях увеличения количества предприятий малого и среднего бизнеса; увеличении самозанятых лиц в области и сферах национальной экономики; повышении конкурентоспособности украинского населения на международных рынках труда, его уверенности в эффективной занятости, реализации возможностей и пожеланий каждого человека, будет способствовать, в свою очередь, установлению прогрессивного гражданского общества (Zahlynska, 2014). Не центровой ли задачей финансово-экономической и кооперативного образования является понимание возможностей самореализации личности как финансово-экономически активного члена общества, способного сознательно приобщаться к финансово-экономического и кооперативного жизни страны (Tovkanets, 2014). Таким образом, в структурно-функциональном разрезе финансово - экономическая и кооперативная образование призвано не только формировать соответствующие знания, но и применять их на развитие общества. Материал исследовательской статьи может быть использован для подготовки учебно-методических пособий, семинаров и образовательных курсов по финансово-экономическим и кооперативных вопросов. Значение/оригинальность. Тематика мало распростра- 
Vol. 2, No. 2, 2016

Baltic Journal of Economic Studies

ненной среди украинских исследователей экономического профиля и более часто попадает в фокус ученых-педагогов. Мы пытались исследовать данное направление через призму финансово-экономического и кооперативного направления образования и ее необходимость для украинского общества на территории западноукраинских земель конца XIX - начала XX века и важность в получении образованности, независимости и благосостояния общества с экономической точки зрения. 